\title{
Effect of Watering Frequency and Growth Media on Seed Germination and Subsequent Seedling of Cardamom (Elleteria Cardamom) at Tepi South-Western Part of Ethiopia
}

\author{
Hassen Seid
}

\begin{abstract}
Cardamom (Elettaria cardamomum Maton - small) is the queen of spices, in the home land for spices. Production is much lower mainly due to constraints such as lack of improved variety, Poor agronomic practices. The long duration taken for seed germination is considered as one of the major issues in the propagation of this crop. Therefore, the current study was conducted with the objective of determining growth media and watering frequency on seed germination and subsequent seedling growth of cardamom. The experiment was conducted at Tepi National Spices Research Center. A split plot design with three replications, Growth media seven levels (Forest soil; Top soil; Forest soil: Top soil; Forest soil: Compost; Top soil: Compost; Forest soil: Top soil : compost; Top soil: Compost) and four levels of watering frequency (every day, two, three \& four days interval) were assigned as main and sub-plot, respectively. The interaction effect was highly significant $(\mathrm{p}<0.05)$ for emergence of seedling. The highest seed germination percentage and speed of germination ( $85 \%$ and 2.94$)$ respectively, were obtained under seeds sown in mixed forest and compost media combination in $(2: 1)$ ratio with watering frequency a day interval. It can be concluded that watering frequency every one day and media of a $(2: 1)$ forest soil and compost combinations improved both seed germination and growth of subsequent seedlings.
\end{abstract}

Keywords: Cardamom, Elettaria cardamomum, Seed germination, watering frequency, growth media

DOI: $10.7176 / \mathrm{JBAH} / 10-7-01$

Publication date: April $30^{\text {th }} 2020$

\section{INTRODUCTION}

Cardamom (Elettaria cardamomum Maton - small) is the queen of spices, in the home land for spices. It was only a wild growth in the evergreen forests of Western Ghats in South India. It is also a clumping plant of up to 20 leaf shoots arising from the rhizome. The shoots are composed of overlapping leafy sheaths, lance late in shape with dark green color (Girma et al. 2008). Some shoots produce flowers on a dropping pinnacle. The cardamom fruits are pale green to yellow in color but turns in to brown when dried and contains 15 to 20 small aromatic seeds about $3 \mathrm{~mm}$ in length which are highly valued as flavoring. Cardamom thrives well, over an altitude of 600 to 1200 m.a.s.l. above (Mean Sea Level), rainfall between $1500 \mathrm{~mm}$ to $4000 \mathrm{~mm}$ and temperature ranging between $10^{\circ}$ $\mathrm{C}$ to $35^{\circ} \mathrm{C}$. Over a period of time people have realized the use and economic potential of cardamom and systematic cultivation was initiated. Apart from being used in food preparation as a flavoring agent, it is also used in confectionary, beverages and liquors. It also has medicinal use in Allopathy and Ayurveda system, (Ankegowda,SJ. 2015).

Cardamom is propagated either by seed or cutting of its clumps, though the latter is by far the most common method, as it yields earlier and ensures a true-to-type propagation than the former. However, vegetative propagation through cuttings results in the destruction of the productive garden, on top of the commonly associated shortage of planting materials to cover wider areas of land. Consequently, seed propagation of cardamom is undertaken to cover large areas of land retaining the mother productive stand intact. But seed germination of cardamom is not fast and/or many seeds not germinate at field condition.

Germination of seeds can be influenced by many factors such as the type of substrate used and environmental factors such as supply of oxygen and water, temperature and light (Hartmann et al., 2007). Growth medium has been found to be the most critical factor in determining seedling growth and development in the nursery and acting as a reservoir for nutrients, moisture and oxygen supply to the growing plant (Baiyeri and Mbah, 2006).

Rooting medium water deficit stress is one of the important factors restricting imbibitions and seed germination and inhibiting seedling growth (Mantovani and Iglesias, 2010). Nursery rooting media mixtures play a key role in improving soil physical and chemical properties and, thereby, increasing, the rate of seed germination and seedling growth and penetrating capacity of roots, suitable environment with proper aeration, sufficient water and nutrient supply was offered by the medium, excellent root system developed, which, in turn, resulted in luxurious growth of plants (Neelam and Ishtiaq, 2011). Therefore, the objective of this study was to evaluate the effect of different soil mixture media compositions and watering frequency on seed germination and subsequent growth of cardamom seedlings.

\section{MATERIALS AND METHOD}

The experiment was conducted at Tepi National Spice Research center during 2013-2015 at nursery condition. It 
is located in Southwest of Ethiopia, SNNP Regional State at an elevation of 1200 m.a.s.l and it situated at Latitude of $7^{0} 10^{\prime} 54.5^{\prime}$ ' $\mathrm{N}$ and with a Longitude of $35^{\circ} 25^{\prime} 04.3-28.2$ ' $\mathrm{E}$ of Ethiopia. The research station receives average rainfall of $1559 \mathrm{~mm}$ annually with maximum and minimum temperatures of $29.7^{\circ}$ cand $15.5^{\circ} \mathrm{c}$, respectively.

A split plot design of three replication was employed with media(forest soil alone, top soil alone, mixture of forest and top soil in 1:1 ratio, forest soil and compost in 2:1 ratio, top soil and compost in 2:1, forest soil, top soil and compost in 2:2:1 ratio, and top soil and compost in 2:1 ratio) and watering frequency treatments (every day, every two days, every three days and every four days interval) were assigned as main plot and subplots, respectively. The seven planting growth growth media consisting of forest soil, top soil and well decomposed compost were filled in to black polythene bag of $16 \mathrm{~cm}$ wide and $22 \mathrm{~cm}$ length. A single experimental unit (plot) consisted of 12 pots. These were arranged in rectangle fashion $(3 \times 4)$ on nursery bed with $15 \mathrm{~cm}$ spacing between experimental units and $20 \mathrm{~cm}$ between replications.

Fully ripened red capsules of released Gene variety of cardamom seeds were harvested and seeds were extracted from the capsules and immediately washed with tap water to remove mucilage. Then, uniform and healthy seeds were selected and prepared for sowing. Three seeds were sown in each pot (polythene bag). Watering frequency treatments were applied for each plot every day, two-day, three-day and four-day interval at field capacity level. When it rains, experimental units (plots) were covered by white plastic sheet. After seedlings emerge thinning to one seedling in a bag was done. All recommended nursery management practices, were implemented uniformly to all experimental units. Germinated seedling count was made for each experimental unit when just it was started (14 days after sowing) every a day interval. This count was extended up to 55 days after sowing. Three months after sowing seedling length $(\mathrm{cm})$ was measured by taking ten seedlings for each experimental unit. Seedlings dry (g) were weighed using sensitive balance. Ten seedlings randomly selected from each replicate were cut free from their cotyledons and placed in envelopes and dried in an oven at $80 \pm 1{ }^{\circ} \mathrm{C}$ for 24 hours. The dried seedlings were calculated to the nearest decimal using sensitive balance and the dry matter yield recorded in $(\mathrm{g})$.

Standard germination $(\%)$ :

Standard Germination test was setup with four replications (100 seeds on in each replication on plastic bag) as per ISTA working guide.

$$
\text { Germination percentage }=\frac{\text { Number of Normal Seedlings }}{\text { Total Number of Seeds Swon }} * 100
$$

Speed of germination

Speed of germination test was determined with a similar procedure to the standard germination test but the number of germinated seeds were counted and removed every day until there was no further germination (ISTA, 2016) working guide.

$$
\frac{n 1}{1}+\frac{n 2}{2}+\cdots+n x / x=N
$$

Where: $n 1 \ldots n x$ are the number of seed germinated on day 1 to day $x 1 \ldots \ldots x$ is the number of days.

\section{Seedling Vigor Test:-}

Seed vigor index I and II were determined as per (ISTA, 2016) by taking 10 randomly selected normal seedlings at the final counting date from each treatment in the standard germination test. The seedling length of the samples (shoot and root length) was measured using a standard ruler. Dry weight (after oven dried $80^{\circ} \mathrm{C}$ for 24 and cooled down for 30 minutes on silica gel) was weighted on a sensitive balance. Vigor Index I and II was then determined by the following formulae (Fiala, 1987). Seed vigor index I = GP x SL and Vigor index II = GP x SDW (g). Where: GP germination percentage, Sl- seedling length, SWD- seedling dry weight

\subsection{Data analysis}

The collected data were processed and analyzed using SAS computer software Version 9.2 (SAS, 2009). The analysis of variance (ANOVA) was employed for each parameters in order to identify the difference among the factors of storage method and period. The significant differences among the treatments were compared using Fisher's Least Significance Difference (LSD) at $<5 \%$ probability level.

\subsection{RESULTS AND DISCUSSION}

\subsection{Interaction effects of growth media and watering frequency on germination percentage and Speed of germination}

The interaction effect of growth media and watering frequency was highly significant $(\mathrm{P}<0.05)$ for both seed germination speed of germination. Highest value of seed germination and speed of germination (85\% and 2.94), respectively, were revealed, seeds sown in a mixture of forest and compost (2:1 ratio) and watering frequency every day interval (Table1 and 2), in contrast, the lowest value (56\% and 0.85$)$, respectively, were revealed for seeds sown in top soil with watering frequency every four days interval. The results obtained from this study 
indicate that cardamom did respond to growth media and level of watering frequency. The lowest germination percentage and speed were observed may be due to the poor ability of moisture holding capacity of the soil for initiating of seedling germination. Okunomo et al.(2009) who obtained a higher germination percentage in top soil with Dacryodes edulis and Persea americana respectively, citing the presence of adequate nutrients for germination and growth in top soil. The assertion contrasted the effect of growth media on germination observed in this study may be explained by Cernac et al. (2006) who stated that germination and seedling emergence is independent of soil nutrient status, but rather depends totally on the cotyledons still attached to the seedling which are rich in stored food reserves until the seedling becomes autotrophic and the ability of the seedlings to utilize these food reserves.

Table I. Interaction of growth media and watering frequency on seed germination (\%)

\begin{tabular}{llllllll}
\hline Watering Frequency & \multicolumn{7}{c}{ Growth media(M) } \\
\cline { 2 - 7 } & Forest & Top & $1 \mathrm{~F}: 1 \mathrm{~T}$ & $2 \mathrm{~F}: 1 \mathrm{C}$ & $2 \mathrm{~T}: 1 \mathrm{C}$ & $2 \mathrm{~F}: 2 \mathrm{~T}: 1 \mathrm{C}$ & $2 \mathrm{~T}: 1 \mathrm{C}$ \\
Every 1day & $68 \mathrm{~b}-\mathrm{e}$ & $78 \mathrm{ab}$ & $72 \mathrm{a}-\mathrm{d}$ & $85 \mathrm{a}$ & $75 \mathrm{a}-\mathrm{c}$ & $72 \mathrm{a}-\mathrm{c}$ & $76 \mathrm{a}-\mathrm{c}$ \\
Every 2days & $84 \mathrm{ab}$ & $75 \mathrm{~b}-\mathrm{e}$ & $66 \mathrm{a}-\mathrm{e}$ & $73 \mathrm{a}-\mathrm{c}$ & $74 \mathrm{a}-\mathrm{c}$ & $73 \mathrm{a}-\mathrm{d}$ & $69 \mathrm{a}-\mathrm{e}$ \\
Every 3days & $76 \mathrm{a}-\mathrm{c}$ & $66 \mathrm{~b}-\mathrm{e}$ & $69 \mathrm{ba}-\mathrm{e}$ & $65 \mathrm{a}-\mathrm{e}$ & $72 \mathrm{a}-\mathrm{e}$ & $80 \mathrm{ab}$ & $66 \mathrm{~b}-\mathrm{e}$ \\
Every 4days & $61 \mathrm{~b}-\mathrm{e}$ & $56 \mathrm{e}$ & $61 \mathrm{c}-\mathrm{e}$ & $61 \mathrm{~b}-\mathrm{e}$ & $66 \mathrm{~b}-\mathrm{e}$ & $61 \mathrm{~b}-\mathrm{e}$ & $61 \mathrm{~b}-\mathrm{e}$ \\
\hline CV\% & 12.3 & & & & & & \\
LSD 5\% & 13.94 & & & & & & \\
\hline
\end{tabular}

Mean values followed by the same letter(s) are not significantly different at $\mathrm{P}<0.05 . \mathrm{M}=\mathrm{Media} \mathrm{F}=\mathrm{Forest}, \mathrm{T}=\mathrm{Top}$, $\mathrm{C}=$ Compost

Table II. Interaction effects of growth media and watering frequency on speed of germination (\%)

\begin{tabular}{llllllll}
\hline \multirow{2}{*}{ Watering Frequency } & \multicolumn{7}{c}{ Growth media(M) } \\
\cline { 2 - 7 } Every 1day & Forest & Top & $1 \mathrm{~F}: 1 \mathrm{~T}$ & $2 \mathrm{~F}: 1 \mathrm{C}$ & $2 \mathrm{~T}: 1 \mathrm{C}$ & $2 \mathrm{~F}: 2 \mathrm{~T}: 1 \mathrm{C}$ & $2 \mathrm{~T}: 1 \mathrm{C}$ \\
Every 2days & $2.42 \mathrm{ab}$ & $2.75 \mathrm{ab}$ & $2.66 \mathrm{ab}$ & $\mathbf{2 . 9 4 a}$ & $2.67 \mathrm{ab}$ & $2.45 \mathrm{ab}$ & $2.71 \mathrm{ab}$ \\
Every 3days & $2.85 \mathrm{ab}$ & $2.75 \mathrm{ab}$ & $2.42 \mathrm{ab}$ & $2.65 \mathrm{ab}$ & $2.59 \mathrm{ab}$ & $2.68 \mathrm{ab}$ & $2.45 \mathrm{ab}$ \\
Every 4days & $2.44 \mathrm{ab}$ & $2.41 \mathrm{ab}$ & $2.42 \mathrm{ab}$ & $2.11 \mathrm{ab}$ & $2.55 \mathrm{ab}$ & $2.78 \mathrm{ab}$ & $2.45 \mathrm{ab}$ \\
\hline Cv\% & $1.77 \mathrm{bc}$ & $\mathbf{0 . 8 5 c}$ & $1.88 \mathrm{ab}$ & $1.85 \mathrm{ab}$ & $1.98 \mathrm{ab}$ & $1.98 \mathrm{ab}$ & $1.10 \mathrm{bc}$ \\
LSD 5\% & 11.3 & & & & & &
\end{tabular}

Mean values followed by the same letter(s) are not significantly different at $\mathrm{P}<0.05 . \mathrm{M}=$ Media $\mathrm{F}=$ Forest, $\mathrm{T}=\mathrm{Top}$, $\mathrm{C}=$ Compost

\subsection{Interaction effects of growth media and watering frequency on seedling length (cm)}

Seedling length significantly affected by interaction of growth media and watering frequency. The highest mean values of seedling length $(34.52 \mathrm{~cm})$ was recorded for seeds sown in forest soil and compost $(2 \mathrm{~F}: 1 \mathrm{C})$ mixture and watering frequency once every day interval. Whereas, the lowest value recorded for seedling length was $(23.00$ $\mathrm{cm}$ ), for seeds sown in top soil and watering frequency every four days interval. The responses of cardamom seed to growth media types and watering frequency could be associated with the variations in physical and chemical characteristics of the media mixture used in this experiment. The observed variations hence indicate the intolerance of cardamom seed to moisture stress and confirm their requirement for a growth medium possessing a relatively higher water holding capacity. From this study the lowest value observed due to less days of watering frequency than growth media This is consistent with the finding of Simon et al. (2011) application of water frequency every day or every two days increase height, survival rate and root volume of the seedling (Table 2).

Table III. Interaction of growth media and watering frequency on seedling length $(\mathrm{cm})$

\begin{tabular}{llllllll}
\hline \multirow{2}{*}{ Watering Frequency } & \multicolumn{7}{c}{ Growth media(M) } \\
\cline { 2 - 7 } Every 1day & Forest & Top & $1 \mathrm{~F}: 1 \mathrm{~T}$ & $2 \mathrm{~F}: 1 \mathrm{C}$ & $2 \mathrm{~T}: 1 \mathrm{C}$ & $2 \mathrm{~F}: 2 \mathrm{~T}: 1 \mathrm{C}$ & $2 \mathrm{~T}: 1 \mathrm{C}$ \\
Every 2days & $17 \mathrm{ef}$ & $24.11 \mathrm{ab}$ & $22.00 \mathrm{bc}$ & $24.52 \mathrm{a}$ & $18.22 \mathrm{~cd}$ & $22.78 \mathrm{ab}$ & $19.41 \mathrm{~cd}$ \\
Every 3days & $20.15 \mathrm{~cd}$ & $20.40 \mathrm{~cd}$ & $10.41 \mathrm{bc}$ & $19.35 \mathrm{~cd}$ & $19.44 \mathrm{~cd}$ & $19.31 \mathrm{~cd}$ & $22.51 \mathrm{ab}$ \\
Every4 days & $22.80 \mathrm{ab}$ & $19.41 \mathrm{de}$ & $17.52 \mathrm{ef}$ & $14.29 \mathrm{fg}$ & $15.00 \mathrm{ef}$ & $21.55 \mathrm{bc}$ & $15.50 \mathrm{ef}$ \\
\hline Cv\% & $16.40 \mathrm{de}$ & $13.00 \mathrm{~g}$ & $17.70 \mathrm{ef}$ & $15.60 \mathrm{ef}$ & $19.35 \mathrm{~cd}$ & $13.58 \mathrm{efg}$ & $21.88 \mathrm{~cd}$ \\
\hline LSD 5\% & 12.3 & & & & & & \\
\hline
\end{tabular}

Mean values followed by the same letter(s) are not significantly different at $\mathrm{P}<0.05$.

$\mathrm{M}=$ Media $\mathrm{F}=$ Forest, $\mathrm{T}=$ Top, $\mathrm{C}=$ Compost

\subsection{Effects of growth media and watering frequency interaction on mean value of days to germination}

The interaction effects of growth media and watering frequency was significant $(\mathrm{P}<0.05)$ for mean day of seedling 
emergency. The highest mean values of days to emergence (51) were recorded for seeds sown in top soil and watering frequency every four days interval. The results indicate late emergence percentage which takes more time and cost. In contrast, seeds sown in mixture of forest and compost soil mixture with (2:1) ratio with watering frequency every day's interval gave minimum days (25) or results early emergence. On the other hand, daily water application reduced the number of mean day's emergence (Table 4). This result similar with result obtained by Mhango et al. (2008) regular watering is necessary to produce good quality seedlings at economic rate. This is because any stagnation in seedling growth or subsequent mortality may bring about huge economic loss to the grower, as seedlings take long to reach an appropriate size for grafting and transplanting or for sale.

Table IV. Interaction of growth media and watering frequency on mean days to emergence

\begin{tabular}{llllllll}
\hline Watering Frequency & \multicolumn{7}{c}{ Growth media(M) } \\
\cline { 2 - 8 } & Forest & Top & $1 \mathrm{~F}: 1 \mathrm{~T}$ & $2 \mathrm{~F}: 1 \mathrm{C}$ & $2 \mathrm{~T}: 1 \mathrm{C}$ & $2 \mathrm{~F}: 2 \mathrm{~T}: 1 \mathrm{C}$ & $2 \mathrm{~T}: 1 \mathrm{C}$ \\
Every 1 Day & $38 \mathrm{bc}$ & $38 \mathrm{bc}$ & $31 \mathrm{bc}$ & $25 \mathrm{c}$ & $32 \mathrm{bc}$ & $44 \mathrm{ab}$ & $38 \mathrm{bc}$ \\
Every 2 Days & $36 \mathrm{bc}$ & $40 \mathrm{bc}$ & $40 \mathrm{bc}$ & $32 \mathrm{bc}$ & $3 \mathrm{bc}$ & $44 \mathrm{ab}$ & $36 \mathrm{bc}$ \\
Every 3 Days & $39 \mathrm{bc}$ & $38 \mathrm{bc}$ & $38 \mathrm{bc}$ & $34 \mathrm{bc}$ & $36 \mathrm{bc}$ & $34 \mathrm{bc}$ & $42 \mathrm{ab}$ \\
Every 4 Days & $50 \mathrm{ab}$ & $51 \mathrm{a}$ & $41 \mathrm{bc}$ & $41 \mathrm{bc}$ & $38 \mathrm{bc}$ & $38 \mathrm{bc}$ & $39 \mathrm{bc}$ \\
\hline Cv\% & 10.77 & & & & & & \\
LSD 5\% & 11.03 & & & & & & \\
\hline
\end{tabular}

Mean values followed by the same letter(s) are not significantly different at $\mathrm{P}<0.05 . \mathrm{M}=\mathrm{Media} \mathrm{F}=\mathrm{Forest}, \mathrm{T}=\mathrm{Top}$, $\mathrm{C}=$ Compost

\subsection{Interaction effects of growth media and watering frequency on seedling vigor index I and II}

The results of the present study indicated that, interaction effects of growth media and watering frequency was highly significant $(\mathrm{P}<0.01)$ for both seedling vigor index I and II. Highest value of seedling vigor index I and II (2080 and 79.57), respectively, were recorded for seeds sown in a mixture of forest soil and compost (2:1 ratio) and watering frequency every day interval (Table 5 and 6). While the lowest value (687 and 66.33), respectively, were revealed for seeds sown in top soil and watering frequency every four days interval. The results obtained from this study indicate that cardamom did respond to media and watering frequency treatments. The lowest seedling vigor index I and II were observed may be due to the poor ability of moisture holding capacity of the soil for initiating of seedling germination. The vigorous and fast growth of seedlings may be attributed to better water holding capacity and availability of nutrients for plant growth in mixture of forest soil and compost in (2:1 ratio) and watering frequency every one day interval. While poor growth top soil and watering frequency every four days may be due to low nutritional status for plant growth offered by the medium. The finding similar with work of Tesfaye et al. (2013) frequent watering resulted in higher rate of shoot growth with greater leaf area, stem diameter, leaf and stem weight and height of seedlings.

Table V. Interaction of growth media and watering frequency on vigor index I

\begin{tabular}{llllllll}
\hline Watering Frequency & \multicolumn{7}{c}{ Growth media(M) } \\
\cline { 2 - 7 } & Forest & Top & $1 \mathrm{~F}: 1 \mathrm{~T}$ & $2 \mathrm{~F}: 1 \mathrm{C}$ & $2 \mathrm{~T}: 1 \mathrm{C}$ & $2 \mathrm{~F}: 2 \mathrm{~T}: 1 \mathrm{C}$ & $2 \mathrm{~T}: 1 \mathrm{C}$ \\
Every 1 Day & $1732 \mathrm{~cd}$ & $1880 \mathrm{~cd}$ & $1584 \mathrm{e}-\mathrm{g}$ & $\mathbf{2 0 8 4 a}$ & $1366 \mathrm{gh}$ & $1724 \mathrm{~cd}$ & $1553 \mathrm{de}$ \\
Every 2 Days & $1688 \mathrm{de}$ & $1530 \mathrm{e}-\mathrm{g}$ & $1079 \mathrm{~h}-\mathrm{l}$ & $1412 \mathrm{fg}$ & $1438 \mathrm{fg}$ & $1409 \mathrm{fg}$ & $1334 \mathrm{gh}$ \\
Every 3 Days & $1156 \mathrm{~g}-\mathrm{i}$ & $1281 \mathrm{gh}$ & $1207 \mathrm{gh}$ & $928 \mathrm{a}-\mathrm{d}$ & $1277 \mathrm{gh}$ & $1640 \mathrm{de}$ & $1023 \mathrm{~g}-\mathrm{i}$ \\
Every 4 Days & $1000 \mathrm{~g}-\mathrm{i}$ & $687 \mathrm{k}$ & $1079 \mathrm{~g}-\mathrm{i}$ & $951 \mathrm{~g}-\mathrm{j}$ & $1080 \mathrm{~g}-\mathrm{i}$ & $828 \mathrm{ij}$ & $1475 \mathrm{fg}$ \\
\hline Cv\% & 9.83 & \multicolumn{7}{c}{} & & & \\
LSD 5\% & 192.5 & & & & & \\
\hline
\end{tabular}

Mean values followed by the same letter(s) are not significantly different at $\mathrm{P}<0.05 . \mathrm{M}=\mathrm{Media} \mathrm{F}=\mathrm{Forest}, \mathrm{T}=\mathrm{Top}$, $\mathrm{C}=$ Compost

Table VI. Interaction of growth media and watering frequency on vigor index II

\begin{tabular}{llllllll}
\hline \multirow{2}{*}{ Watering Frequency } & \multicolumn{7}{c}{ Growth media(M) } \\
\cline { 2 - 7 } Every 1 Day & Forest & Top & $1 \mathrm{~F}: 1 \mathrm{~T}$ & $2 \mathrm{~F}: 1 \mathrm{C}$ & $2 \mathrm{~T}: 1 \mathrm{C}$ & $2 \mathrm{~F}: 2 \mathrm{~T}: 1 \mathrm{C}$ & $2 \mathrm{~T}: 1 \mathrm{C}$ \\
Every 2 Days & $71.3 \mathrm{f}-\mathrm{k}$ & $67.9 \mathrm{k}-\mathrm{m}$ & $74.5 \mathrm{~b}-\mathrm{g}$ & $\mathbf{7 9 . 5 7 a}$ & $76.3 \mathrm{a}-\mathrm{d}$ & $72.1 \mathrm{~d}-\mathrm{k}$ & $74.1 \mathrm{c}-\mathrm{h}$ \\
Every 3 Days & $70.7 \mathrm{f}-\mathrm{m}$ & $70.2 \mathrm{~g}-\mathrm{m}$ & $74.1 \mathrm{c}-\mathrm{i}$ & $74.6 \mathrm{~b}-\mathrm{g}$ & $77.5 \mathrm{a}-\mathrm{c}$ & $73.7 \mathrm{c}-\mathrm{j}$ & $69.3 \mathrm{j}-\mathrm{m}$ \\
Every 4 Days & $73.7 \mathrm{c}-\mathrm{j}$ & $67.4 \mathrm{~km}$ & $74.6 \mathrm{~b}-\mathrm{g}$ & $74.0 \mathrm{c}-\mathrm{i}$ & $70.6 \mathrm{~g}-\mathrm{k}$ & $69.8 \mathrm{~h}-\mathrm{m}$ & $71.1 \mathrm{f}-\mathrm{k}$ \\
\hline Cv\% & $73.2 \mathrm{c}-\mathrm{j}$ & $\mathbf{6 6 . 3 m}$ & $66.3 \mathrm{~m}$ & $73.6 \mathrm{c}-\mathrm{j}$ & $73.4 \mathrm{c}-\mathrm{j}$ & $61.5 \mathrm{e}-\mathrm{k}$ & $73.6 \mathrm{c}-\mathrm{j}$ \\
LSD 5\% & 9.84 & \multicolumn{7}{c}{} & & & & & \\
\hline
\end{tabular}

Mean values followed by the same letter(s) are not significantly different at $\mathrm{P}<0.05 . \mathrm{M}=\mathrm{Media} \mathrm{F}=\mathrm{Forest}, \mathrm{T}=\mathrm{Top}$, $\mathrm{C}=$ Compost 


\subsection{CONCLUSION}

Based on the current finding, the results obtained, cardamom seeds sown in mixed forest soil and compost media in 2:1 ratios and watering frequency every day are advised to be used for early and high percentage of emergence. According to the present results of this study it can be concluded that soil media and watering frequency improved both seed germination, rate of emergency and growth of cardamom seedlings.

\subsection{ACKNOWLEDGEMENT}

I would like to thanks Tepi National spices Research Center and Technology Multiplication and Seed Research Directorate, EIAR, for the financial and unreserved moral support during research work. Finally we would like to thank the publishers as well.

\subsection{REFERENCE}

Baiyeri KP, Mbah BN (2006). Effects of soilless and soil based nursery media on seedling emergence, growth and response to water stress of African breadfruit (Treculia africana Decne). Afr. J. of biotechnol.,, 5: 1405-1410.

Cernac A, Andre C, Hoffmann-Benning S, Benning C(2006). WRI1 is required for seed germination and seedling establishment1. Plant Physiol., 141: 745-757.

Fiala, F. 1987. Handbook of vigour test methods, ISTA publication, and second edition. Zuerich, Swzerland.

Girma Hailemichael, Digafie Tilahun, Edossa Etissa, Belay Yemanebirhan and Weyessa Garedew. 2008. Spices research achievements, revised edition, Ethiopian Institut of Agricultural Research, Addis Ababa, Ethiopia.

ISTA. 2016. International Seed Testing Association. International rule for seed testing. Bassersdorf, Switzerland.

Mhango J, Akinnifesi FK, Mng'omba SA, Sileshi G (2008). Effect of growing medium on early growth and survival of Uapaca kirkiana Müell Arg. seedlings in Malawi. Afr. J. Biotechnol., 7(13): 2197-2202.

Neelam A, Ishtiaq M (2001). Response of Eucalyptus camaldulensis seedlings to different soil media. Sarhad J. Agric., 17(1): 75-79. Okunomo K, Ogisi DO, Bosah BO (2009). Effect of growth media on germination and seedling growth of Persea americana (Mill). J. of food, Agric. and Environ., 7(1): 111-113.

Okunomo K, Ogisi DO, Bosah BO (2009). Effect of growth media on germination and seedling growth of Perseaamericana(Mill). J. of food, Agric. and Environ., 7(1): 111-113.

SAS (Statistical Analysis System), (2008). (Version 9.2). SAS Institute, Cary, NC. USA.

Simon AM, Festus KA, Gudeta S, Oluyede CA, Betserai IN, Ramni J (2011). Water application rate and frequency affect seedling survival and growth of Vangueria infausta and Persea americana: Afr. J. of Biotechnol., 10(9): 12.

Simon AM, Festus KA, Gudeta S, Oluyede CA, Betserai IN, Ramni J (2011). Water application rate and frequency affect seedling survival and growth of Vangueria infausta and Perseaamericana: Afr. J. of Biotechnol., 10(9): 12.

Tesfaye S, Mohad G, Razi I, Kausar H, Marziah M, Ramlan MF (2013). Plant water relations,crop yield and quality in Coffee(coffee Arabica L) as influenced by partial root zone drying and deficit irrigation.AJCS(g) : 1361-1368. 